\title{
Association between somatic cell count early in the first lactation and the lifetime milk yield of cows in Irish dairy herds
}

\author{
S. C. Archer, ${ }^{* 1}$ F. Mc Coy, † W. Wapenaar, ${ }^{*}$ and M. J. Green* \\ *University of Nottingham, School of Veterinary Medicine and Science, Sutton Bonington Campus, Sutton Bonington, Leicestershire, \\ LE12 5RD, United Kingdom \\ †Animal and Grassland Research and Innovation Centre, Teagasc, Moorepark, Fermoy, Co. Cork, Ireland
}

\section{ABSTRACT}

Change in lifetime milk yield is an important component of the cost of diseases in dairy cows. Knowledge of the likelihood and scale of potential savings through disease prevention measures is important to evaluate how much expenditure on control measures is rational. The aim of this study was to assess the association between somatic cell count (SCC) at 5 to $30 \mathrm{~d}$ in milk during parity 1 (SCC1), and lifetime milk yield for cows in Irish dairy herds. The data set studied included records from 53,652 cows in 5,922 Irish herds. This was split into 2 samples of 2,500 and 3,422 herds at random. Linear models with lifetime milk yield and first-lactation milk yield as the outcomes and random effects to account for variation between herds were fitted to the data for the first sample of herds; data for the second sample were used for cross-validation. The models were developed in a Bayesian framework to include all uncertainty in posterior predictions and parameters were estimated from 10,000 Markov chain Monte Carlo simulations. The final model was a good fit to the data and appeared generalizable to other Irish herds. A unit increase in the natural logarithm of SCC1 was associated with a median decrease in lifetime milk yield of $864 \mathrm{~kg}$, and a median decrease in first-lactation milk yield of $105 \mathrm{~kg}$. To clarify the meaning of the results in context, microsimulation was used to model the trajectory of individual cows, and evaluate the expected outcomes for particular changes in the herdlevel prevalence of cows with SCC1 $\geq 400,000$ cells $/ \mathrm{mL}$. Differences in mean lifetime milk yield associated with these changes were multiplied by an estimated gross margin for each cow to give the potential difference in milk revenue. Results were presented as probabilities of savings; for example, a $75 \%$ probability of savings of at least $€ 97$ or $€ 115 /$ heifer calved into the herd existed if the prevalence of cows with SCC1 $\geq 400,000$ cells/

Received October 20, 2012.

Accepted January 20, 2013.

${ }^{1}$ Corresponding author: svxsa@nottingham.ac.uk
$\mathrm{mL}$ was reduced from $\geq 20$ to $<10$ or $<5 \%$, respectively, and at least $€ 71 /$ heifer calved into the herd if the prevalence of cows with SCC1 $\geq 400,000$ cells $/ \mathrm{mL}$ was reduced from $\geq 10$ to $<5 \%$. The results indicate large differences in lifetime milk yield, depending on SCC early in the first lactation and the findings can be used to assess where specific interventions to control heifer mastitis prepartum are likely to be cost effective.

Key words: dairy heifer, somatic cell count, lifetime milk yield

\section{INTRODUCTION}

Mastitis in primiparous cows early in their first lactation has been highlighted as a common problem that is economically important through its impact on their future productivity (Piepers et al., 2009; De Vliegher et al., 2012), which limits their ability to achieve genetic potential for milk yield. Increased SCC early in the first lactation (SCCel) has been associated with decreased milk yield throughout the entire first lactation (Coffey et al., 1986; De Vliegher et al., 2005b). This loss has been estimated in Belgian primiparous cows at 0.13 $\mathrm{kg} / \mathrm{d}$ for every unit increase in the natural logarithmtransformed SCC measured between 5 and 14 DIM (De Vliegher et al., 2005b). The relationship between SCCel and cumulative milk yield in subsequent lactations is less clear. Coffey et al. (1986) reported that for cows in Virginia, the mean first-lactation milk yield decreased with increasing SCCel, and was 6,452, 6,050, and 5,696 $\mathrm{kg}$ for groups of cows with SCCel $<100,000,100,000$ to 400,000 , and $>400,000$ cells $/ \mathrm{mL}$, respectively. However, over subsequent lactations beyond the first, this trend did not continue and mean lactation milk yields were $6,840,7,241$, and $7,163 \mathrm{~kg}$, respectively, for the same groups (Coffey et al., 1986). Their study did not control for clustering of cows in different herds, any potential confounding variables, or importantly, how long cows survived. The effect of SCCel on lifetime milk yield has not otherwise been considered. This is an important omission, as it may not be until cows reach their second lactation that sufficient milk is produced to break even 
on rearing costs, and the true cost of milk loss may extend further than the first lactation. For example, under Irish conditions, the cost of rearing to the point of calving is approximately $€ 1,451$ /heifer (Kennedy et al., 2011). Therefore, with an average margin over variable costs of $€ 0.17 / \mathrm{kg}$ (Hennessy et al., 2011), 8,535 kg of saleable milk is required to break even, which likely requires $>1$ lactation. Furthermore, primiparous cows have yet to achieve their full adult weight and size; lactation milk yield and hence financial return on investment increases in subsequent lactations (Madouasse, 2009). Considering the impact on lifetime milk yield is, therefore, important to evaluate the total cost of SCCel, and aid decision making around mastitis control measures for heifers prepartum.

The aim of this study was to assess the association between SCC at 5 to 30 DIM during parity 1 (SCC1) and lifetime milk yield for cows in Irish dairy herds. A Bayesian approach was taken, and posterior predictions were used to evaluate the economic impact of the results on meaningful, intuitive scales, and for particular herd scenarios.

\section{MATERIALS AND METHODS}

\section{Data Selection}

To be eligible for inclusion in the study, cows required an SCC recording between 5 and 30 DIM during parity 1. Cows were initially selected from a data set of Irish dairy herds based on test-day recordings between 2005 and 2009 that contained 233,176 cows in 7,423 herds. A sub-dataset of production records from $25 \%$ of these cows, with a record of SCC1 between January 2005 and March 2007, and with dates of birth available was then created. Cows with age at first calving $($ AFC) $<700$ $\mathrm{d}$ were deemed at increased risk of culling because of dystocia (Berry and Cromie, 2009) and individual cows with AFC $<700 \mathrm{~d}$ ( $6 \%$ of the total population) were discarded to remove this effect. For the selected cows, cumulative milk yields for all lactations up to July 25 , 2012, were determined based on a published method (Olori et al., 1999). These were summed to give an estimate of lifetime milk yield for each cow over followup times from 5.3 to $8.5 \mathrm{yr}$, based on the time from the first calving to the end of the study period for each cow. The selected data set included records from 53,652 cows in 5,922 herds. Random samples of 2,500 (samp_1), and 3,422 (samp_2) of these herds were selected using $\mathrm{R}$ software (R Development Core Team, 2010) and the data for all 22,023 and 31,629 eligible cows in samp_1 and samp_2, respectively, were collated. The statistical models were fitted to samp_1, and samp_2 was used for cross-validation; sample sizes were determined based on the computational constraints imposed by these procedures. Median, and interquartile range (IQR) for lifetime milk yield, first-lactation milk yield, proportion of cows surviving lactations 1 and 4 , and SCC1 were determined for each sample, stratified by subgroups based on SCC1 (group 1: $<55,000$ cells/mL; group 2: 55,000 to 149,000 cells/mL; group 3: 150,000 to 400,000 cells/mL; group 4: >400,000 cells/mL).

\section{Statistical Analysis}

The outcomes used were lifetime milk yield, or firstlactation milk yield $\left(\mathrm{y}_{\mathrm{ij}}\right)$ for the ith cow in the jth herd. Random effects models were developed for samp_1; these took the following form:

$$
\begin{gathered}
\mathrm{y}_{\mathrm{ij}}=\alpha+\mathbf{X}_{\mathrm{ij}} \boldsymbol{\beta}_{1}+\mathbf{X}_{\mathbf{j}} \boldsymbol{\beta}_{2}+\mathrm{u}_{\mathrm{j}}+\mathrm{e}_{\mathrm{ij}}, \\
\mathrm{u}_{\mathrm{j}} \sim \operatorname{normal}\left(0, \sigma_{\mathrm{u}}^{2}\right), \\
\mathrm{e}_{\mathrm{ij}} \sim \operatorname{normal}\left(0, \sigma_{\mathrm{e}}^{2}\right),
\end{gathered}
$$

where $\alpha=$ intercept value; $\mathbf{X}_{\mathbf{i j}}=$ matrix of exposure variables for each cow; $\boldsymbol{\beta}_{1}=$ vector of coefficients for $\mathbf{X}_{\mathrm{ij}} ; \mathbf{X}_{\mathbf{j}}=$ matrix of exposure variables for each herd; $\boldsymbol{\beta}_{\mathbf{2}}$ $=$ vector of coefficients for $\mathbf{X}_{\mathbf{j}} ; \mathbf{u}_{\mathrm{j}}=$ a random effect to account for residual variation between herds, assumed to be normally distributed, with mean $=0$ and variance $=\sigma_{u}^{2}$; and $e_{i j}=$ residual level 1 error, assumed to be normally distributed, with mean $=0$ and variance $=$ $\sigma_{\mathrm{e}}^{2}$. Somatic cell count 1 was the exposure of interest for each cow, and was included on a natural logarithmic scale. To focus attention on the prepartum period for the control of heifer mastitis, only confounding variables deemed to be operating by 30 DIM during parity 1 were selected. De Vliegher et al. (2005b) identified DIM at the first recording as a confounding variable between SCCel and first-lactation milk yield. Therefore, polynomials for the natural logarithm of AFC and DIM at the first recording were investigated for inclusion. Due to the importance of seasonal production to Irish dairy herds (Archer et al., 2013a), month and year of first calving were included as categorical terms. Biologically plausible interactions and herd-level random slopes (herd $\times$ fixed effect interactions) were assessed. Initial values for all covariates were generated using MLwiN software (Rasbash et al., 2012), with the iterative generalized least squares procedure (Goldstein, 2003). To facilitate posterior predictions that incorporated all uncertainty in parameters, the models were developed in a Bayesian framework using WinBUGS 1.4.3 software (Lunn et al., 2000). Parameters were es- 
timated from 10,000 Markov chain Monte Carlo simulations, following a burn-in of 1,000 simulations, during which time chain convergence occurred [determined by visual inspection of 3 chains to ensure that a stationary distribution had been reached (Gilks et al., 1996)]. Vague prior distributions were used for $\sigma_{\mathrm{u}}^{-2} \sim$ gamma $(0.001,0.001), \sigma_{\mathrm{e}}^{-2} \sim$ gamma $(0.001,0.001)$, and $\boldsymbol{\beta} \sim$ normal $\left(0,10^{6}\right)$ to give the major influence to the data in the estimation of parameters (Green et al., 2004). Distributions of covariates and interaction terms were inspected; these remained in the model based on biological plausibility, and if the $95 \%$ Bayesian credible interval (BCI) excluded 0. Sensitivity of the results to prior distributions for the herd-level random effect variance (Spiegelhalter et al., 2004) was evaluated by repeating simulations using the prior $\sigma_{\mathrm{u}}^{2} \sim$ uniform $\left(10^{-8}, 10^{8}\right)$.

\section{Model Checking}

For both models, the posterior distribution of the mean residual from samp_1 was inspected to determine if the $95 \%$ BCI included 0, suggesting adequate model fit. To further evaluate fit and usefulness of the lifetime milk yield model (Gelman et al., 1996) that was used in the following microsimulation, fixed and random effects were used to predict cow life time milk yield $\left(y \cdot \operatorname{pred}_{\mathrm{ij}}\right)$ as follows:

$$
\begin{aligned}
& \text { y.pred }_{i j} \sim p\left(y \cdot \operatorname{pred}_{i j} \mid \boldsymbol{\beta}, \text { samp_1, } u_{j}\right) \text {, }
\end{aligned}
$$

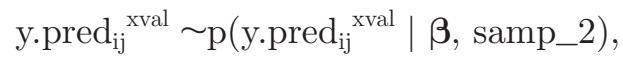

where $y \cdot \operatorname{pred}_{\mathrm{ij}}$ and $y \cdot \operatorname{pred}_{\mathrm{ij}}{ }^{\mathrm{xval}}$ are posterior predictions of lifetime milk yield for the ith cow in the jth herd in samp_1 and samp_2, respectively; $\boldsymbol{\beta}$ is the vector of model coefficient distributions; and $\mathrm{u}_{\mathrm{j}}$ is the random effect for the jth herd in samp_1. Predicted and observed mean lifetime milk yields were calculated for cows categorized by subgroups based on SCC1; these categories were not in the final models. Posterior predicted distributions of mean lifetime milk yield for cows in these groups were inspected to determine if the observed mean lifetime milk yields were within the $95 \%$ $\mathrm{BCI}$ of the posterior predictions, indicating the extent of model usefulness for predictions based on SCC1, and if the results could potentially be generalized to other Irish dairy herds (Gelman et al., 1996).

\section{Microsimulation}

To illustrate the impact of SCC1 on lifetime milk yield at herd level, and to demonstrate financial relevance, a procedure known as microsimulation was used (Spiegelhalter et al., 2004). This method involves a simulation to model the trajectory of individual cows and, thus, evaluate the expected outcomes for particular scenarios, with all variability in the model parameters and dependence between variables included (Spiegelhalter et al., 2004). This method allows the impact of SCC1 (the effect of interest) to be evaluated in the absence of confounding influences, as if a carefully controlled trial had been carried out. Therefore, the Bayesian model for lifetime milk yield was extended to include a one-step microsimulation for 1,000 theoretical cows with different characteristics, in herds with an initial prevalence of cows with SCC1 $\geq 400,000$ cells $/ \mathrm{mL}$ (SCC1_hi) of $\geq 20$ and $\geq 10 \%$. For each cow, values for the natural logarithm of SCC1 were drawn from normal distributions (determined from the initial data set) for herds grouped by SCC1_hi prevalence (Table 1). To demonstrate the impact of achievable reductions in SCC1_hi prevalence on lifetime milk yield at herd level, herds with an initial SCC1_hi prevalence $\geq 20 \%$ were deemed to reduce this to $<10$ or $<5 \%$, and herds with an initial SCC1_hi prevalence $\geq 10 \%$, were deemed to reduce this to $<5 \%$ (Table 1 ). To provide a straightforward comparison between different herd scenarios, all simulated cows had a first calving date in February 2005. At each of 10,000 Markov chain Monte Carlo simulations (following a burn-in of 1,000), final model coefficients were combined with data from the theoretical cows to generate predictions of lifetime milk yield for the ith cow in the jth herd $\left(y \cdot \operatorname{pred}_{\mathrm{ij}}\right)$ :

$$
\mathrm{y} \operatorname{pred}_{\mathrm{ij}} \sim \mathrm{p}\left(\mathrm{y}_{\operatorname{pred}} \operatorname{prj}_{\mathrm{ij}} \mid \boldsymbol{\beta}, \mathbf{X}^{\mathrm{sim}}\right),
$$

where $\boldsymbol{\beta}$ is a vector of model coefficient distributions and $\mathbf{X}^{\text {sim }}$ is a matrix of data for simulated cows, including a simulated value for the natural logarithm of SCC1, based on the herd-level prevalence of SCC1_hi (Table 1), and indicator variables to denote a first calving in February 2005.

\section{Change in Revenue From Lifetime Milk Yield}

At each iteration, mean lifetime milk yield for the simulated cows in each herd scenario was calculated. Differences in mean lifetime milk yield were multiplied by an estimated gross margin (milk price - variable costs of production), which was drawn from a normal distribution with mean $=0.17 € / \mathrm{L}$ and variance $=$ $0.03^{2} \epsilon^{2} / \mathrm{L}^{2}$ for each cow (Hennessy et al., 2011), to give the difference in expected revenue associated with reductions in the prevalence of cows with SCC1_hi. Posterior distributions of revenue change per heifer calved into the herd were plotted as a cumulative frequency 
Table 1. Frequency of 7,423 Irish dairy herds categorized by prevalence of cows with $\mathrm{SCC} 1^{1} \geq 400,000$ cells/ $\mathrm{mL}$ and mean and (variance) for the natural logarithm of SCC measured between 5 and 30 DIM for 233,176 primiparous cows in these herds

\begin{tabular}{lcccc}
\hline & \multicolumn{3}{c}{ Herd-level prevalence of cows with SCC1 $\geq 400,000$ cells $/ \mathrm{mL}$} \\
\cline { 2 - 5 } Item & $\geq 10 \%$ & $\geq 20 \%$ & $<5 \%$ & $<10 \%$ \\
\hline Percentage of herds & 55 & 19 & 25 & 45 \\
ln SCC1 & $4.79(1.52)$ & $5.11(1.78)$ & $4.26(0.80)$ & $4.39(1.04)$ \\
\hline
\end{tabular}

${ }^{1}$ First test-day SCC record between 5 and 30 DIM during parity 1.

distribution to show the probability of different levels of financial return.

\section{RESULTS}

\section{Descriptive Results}

Summary measures were similar in samp_1 and samp_2 (Table 2). In samp_1, median lifetime milk yield (IQR) decreased from 23.8 (11.5 to 36.4) t for cows with SCC1 $<55,000$ cells $/ \mathrm{mL}$ to 18.9 (8.7 to 31.9 ) $\mathrm{t}$ for cows with SCC1 $>400,000$ cells $/ \mathrm{mL}$. The median first-lactation milk yield (IQR) decreased from 5.5 (4.5 to 6.9$)$ t for cows with $\mathrm{SCC} 1<55,000$ cells $/ \mathrm{mL}$ to 5.2 (4.2 to 6.5) t for cows with SCC1 $>400,000$ cells $/ \mathrm{mL}$. A trend was observed for decreased proportions of cows surviving beyond the first and fourth lactation with increasing SCC1 (Table 2).

\section{Model Results}

Unit increase in the natural logarithm of SCC1 was associated with a median decrease in lifetime milk yield of 864 (95\% BCI: 706 to 1,024) kg, and a median decrease in first-lactation milk yield of 105 (95\% BCI: 77 to 133) $\mathrm{kg}$ (Table 3). The final models adjust for month and year of first calving. Cows that first calved in June 2007, with mean natural logarithm of SCC1, were the baseline for comparison, although lifetime milk yield did not differ between the relatively few heifers that calved from April to August (95\% BCI included 0). Heifers calving in January had the highest lifetime milk yield and produced a median of 5,550 (95\% BCI: 4,055 to 7,027$) \mathrm{kg}$ more milk than those calving in June. The next highest month of first calving was October and these heifers produced a median of 4,695 (95\% BCI: $2,944$ to 6,449$) \mathrm{kg}$ more milk than those calving in June.

Table 2. Descriptive results for subgroups of eligible Irish primiparous dairy cows, ${ }^{1}$ based on SCC between 5 and 30 DIM (SCC1); medians and interquartile range of SCC1 and lifetime milk yield; and proportions of cows surviving beyond the first and fourth lactation

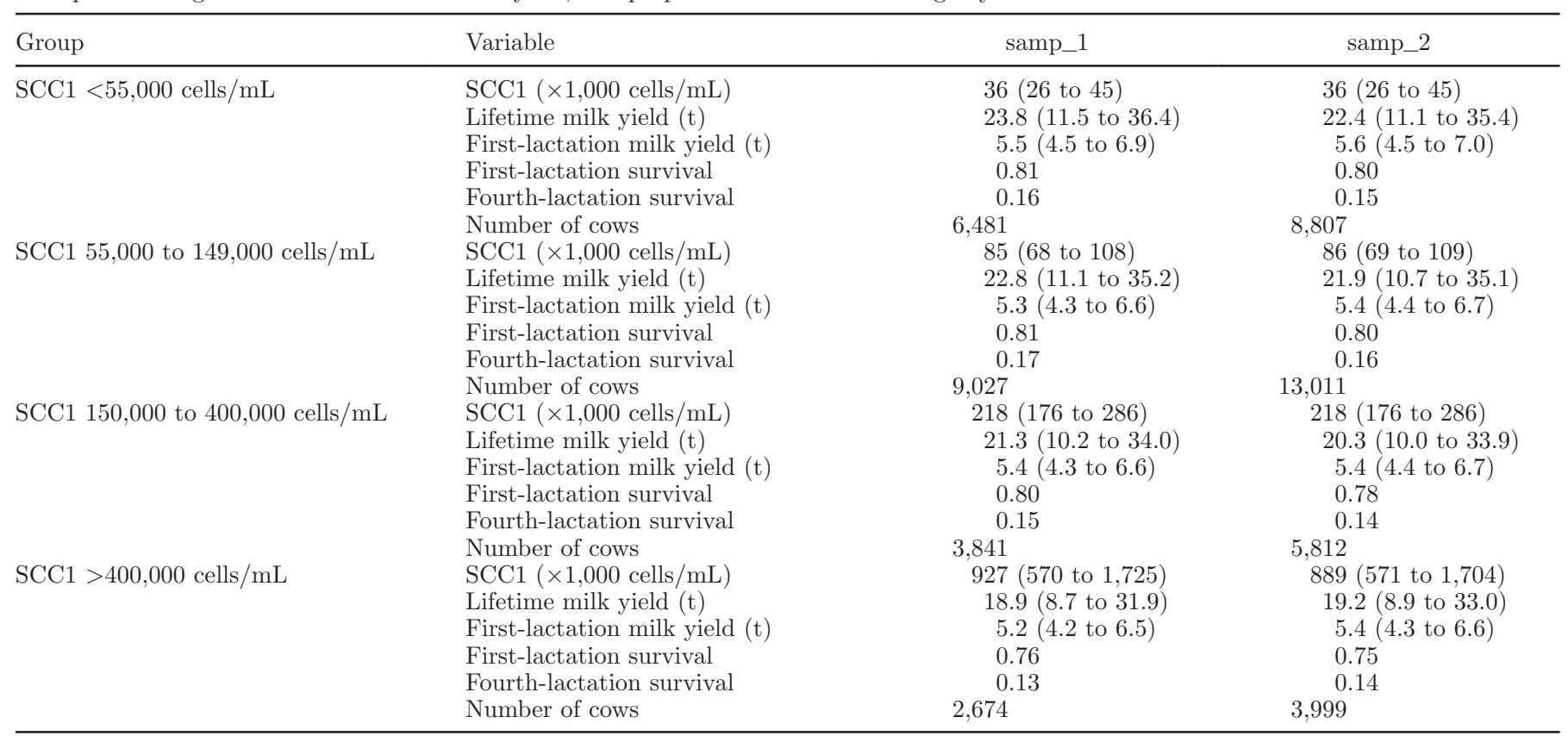

${ }^{1}$ Includes eligible cows from 2,500 herds used for model development (samp_1) and 3,422 herds used for cross-validation (samp_2). 
Table 3. Bayesian credible intervals from 10,000 simulations of the final models: outcomes of cow-level lifetime and first-lactation milk yields $(\mathrm{kg})$

\begin{tabular}{|c|c|c|c|c|c|c|}
\hline \multirow[b]{2}{*}{ Item } & \multicolumn{3}{|c|}{ Lifetime milk yield (kg) } & \multicolumn{3}{|c|}{ First-lactation milk yield (kg) } \\
\hline & $\begin{array}{c}\text { Lower } \\
2.5 \%\end{array}$ & Median & $\begin{array}{l}\text { Upper } \\
97.5 \%\end{array}$ & $\begin{array}{c}\text { Lower } \\
2.5 \%\end{array}$ & Median & $\begin{array}{l}\text { Upper } \\
97.5 \%\end{array}$ \\
\hline \multicolumn{7}{|c|}{ Exposure (baseline) } \\
\hline Intercept & $-4,545$ & 10,890 & 26,260 & 241 & 2,954 & 5,642 \\
\hline $\ln \mathrm{SCC}^{1}(4.65)$ & $-1,024$ & -864 & -706 & -133 & -105 & -77 \\
\hline \multicolumn{7}{|c|}{ Mo of first calving (June) } \\
\hline January & 4,055 & 5,550 & 7,027 & 370 & 640 & 900 \\
\hline February & 2,978 & 4,396 & 5,786 & -13 & 237 & 479 \\
\hline March & 1,523 & 2,936 & 4,353 & -334 & -83 & 167 \\
\hline April & -81 & 1,373 & 2,807 & -568 & -308 & -55 \\
\hline May & -815 & 801 & 2,397 & -664 & -380 & -99 \\
\hline July & $-2,493$ & -19 & 2,400 & 446 & 876 & 1,307 \\
\hline August & $-1,096$ & 1,306 & 3,972 & 930 & 1,358 & 1,780 \\
\hline September & 1,315 & 3,147 & 4,948 & 946 & 1,270 & 1,586 \\
\hline October & 2,944 & 4,695 & 6,449 & 1,141 & 1,449 & 1,752 \\
\hline November & 1,973 & 3,827 & 5,750 & 904 & 1,226 & 1,551 \\
\hline December & 1,317 & 3,477 & 5,721 & 887 & 1,263 & 1,642 \\
\hline \multicolumn{7}{|c|}{ Year of first calving (2007) } \\
\hline 2004 & $-3,865$ & 11,790 & 27,520 & -856 & 1,872 & 4,578 \\
\hline 2005 & $-5,605$ & 9,646 & 25,010 & -186 & 2,487 & 5,180 \\
\hline 2006 & $-8,010$ & 7,305 & 22,660 & -100 & 2,587 & 5,278 \\
\hline $\ln \mathrm{AFC}^{2}(6.71)$ & $-8,320$ & $-6,906$ & $-5,470$ & $\mathrm{NA}^{3}$ & NA & NA \\
\hline \multicolumn{7}{|l|}{ Random effect SD } \\
\hline Cow level & 12,763 & 12,888 & 13,019 & 2,215 & 2,237 & 2,260 \\
\hline Herd level & 6,752 & 7,053 & 7,372 & 1,226 & 1,318 & 1,374 \\
\hline
\end{tabular}

${ }^{1}$ First test-day SCC record between 5 and 30 DIM during parity 1 .

${ }^{2} \mathrm{AFC}=$ age at first calving $(\mathrm{d})$.

${ }^{3} \mathrm{NA}=$ not applicable.

In contrast, the first-lactation milk yield was highest for heifers calving from August to December (Table 3). Lifetime and first-lactation milk yields did not differ by year of first calving (95\% BCI included 0). Inclusion of AFC had no substantive effect on the coefficient distribution for the natural logarithm of SCC1. Decrease in AFC from 27 to 24 mo was associated with a median increase in lifetime milk yield of 760 (95\% BCI: 602 to $915) \mathrm{kg}$ and was not associated with first-lactation milk yield (95\% BCI included 0).

\section{Model Checking}

The posterior distribution of the mean residuals for samp_1 were normal, with medians of 6.0 (95\% BCI: -242 to 247$) \mathrm{kg}$ and 0.3 (95\% BCI: -43 to 43$)$ for the outcomes lifetime milk yield and first-lactation milk yield, respectively. Therefore, the final models fitted the data on which they were developed. Predictions of lifetime milk yield for cows in samp_1 aggregated by SCC1 group also indicated good fit and, hence, this model was adequate for predictions in these herds (Figure 1). The final model for lifetime milk yield also appeared generalizable to other Irish dairy herds, as the observed mean lifetime milk yield for cows in samp_2 aggregated by SCC1 group was within the
95\% BCI of posterior predictions (Figure 1). There was $\leq 0.4 \%$ difference in the median and $95 \%$ BCI limits of the natural logarithm of SCC1 coefficient distribution when a uniform prior distribution for the herd-level random effect variance was used, and this had no substantive effect on interpretation of the final model results.

\section{Microsimulation Results}

Figure 2 shows the probability of different levels of potential revenue change for every heifer calved into the herd attributable to increased lifetime milk yield for various herd-level reductions in SCC1_hi prevalence. For example, a $75 \%$ certainty of savings of at least $€ 97$ or $€ 115 /$ heifer calved into the herd existed if the prevalence of cows with SCC1_hi was reduced from $\geq 20$ to $<10$ or $<5 \%$, respectively, and at least $€ 71 /$ heifer calved into the herd if the prevalence of cows with SCC1_hi was reduced from $\geq 10$ to $<5 \%$ (Figure 2 ). Therefore, for a herd that calves 20 heifers/yr, $\geq 4$ of which have SCC1_hi, there would be $75 \%$ certainty of saving at least $€ 1,940 / y r$ if the number with SCC1_hi could be reduced to $\leq 1$. Table 4 gives savings in further scenarios and at different levels of certainty for this example herd. 

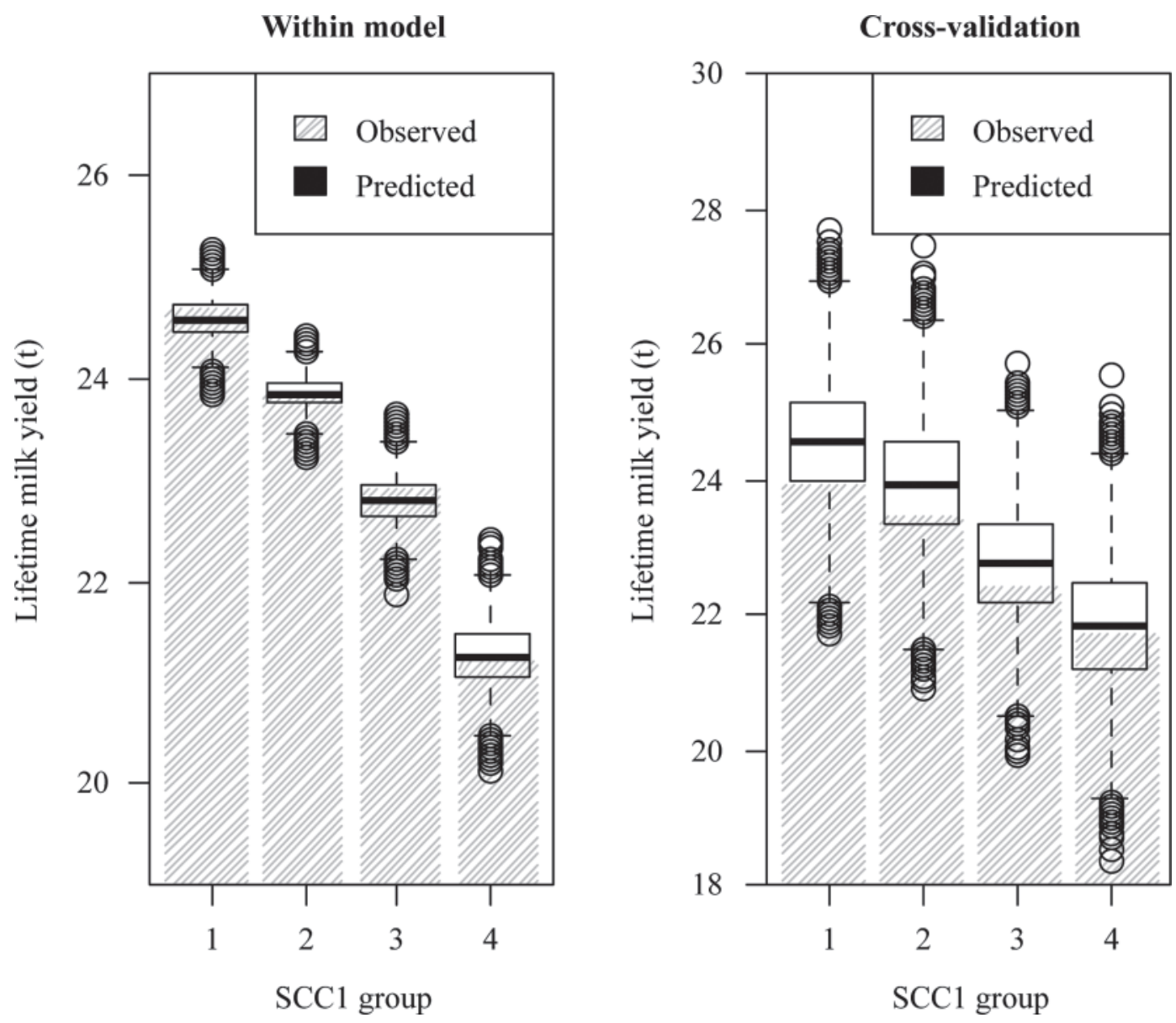

Figure 1. Final model predictions of lifetime milk yield from 10,000 simulations and observed values in 2,500 Irish dairy herds used for model development and 3,422 separate Irish dairy herds used for cross-validation [grouped by SCC between 5 and 30 DIM during parity1 (SCC1): group 1: $<50,000 / \mathrm{mL}$; group 2: 50,000 to 149,000/mL; group 3: 150,000 to 400,000/mL; group 4: >400,000/mL]; the horizontal bold line is the median; the surrounding box contains $50 \%$ of the data; the vertical whiskers extend to 1.5 times the interquartile range, and outliers are shown beyond this.

\section{DISCUSSION}

To the authors' knowledge, this study is the first to demonstrate large differences in the lifetime milk yield of cows, depending on SCC early in the first lactation. The median decrease in lifetime milk yield of $864 \mathrm{~kg} /$ unit increase in the natural logarithm of SCC early in the first lactation observed in this study (for example, from 55,000 to 150,000 cells $/ \mathrm{mL}$, or 150,000 to 400,000 cells $/ \mathrm{mL}$ ) incorporated a milk loss of $105 \mathrm{~kg}$ in the first lactation. For comparison, this is larger than the estimate made by De Vliegher et al. (2005b) of approximately $47 \mathrm{~kg}$ within $365 \mathrm{~d}$ of first calving per unit increase in the natural logarithm of SCC at 5 to 14 DIM. Importantly, the analysis of De Vliegher et al. (2005b) was conditional on cows surviving the first lactation and, hence, showed the milk loss in affected primiparous cows that survived, likely associated with residual udder pathology, but excluding milk loss associated with premature culling.

Therefore, the decrease in lifetime milk yield was considerably more than the losses occurring in the first lactation. This highlights the usefulness of using cumulative measures of milk yield, rather than test-day records alone, specifically to account for how long cows actually remain productive in addition to decreased milk production per se. High SCC early in the first lactation has been associated with premature culling of cows in both Irish (Archer et al., 2013b) and Belgian dairy herds (De Vliegher et al., 2005a) and this appears to cause financial losses mostly through a decrease in lifetime milk yield rather than through the additional replacement costs incurred with premature culling (Archer et al., 2013b).

Gelman et al. (1996) have proposed that demonstrating the extent to which models are useful, rather than 


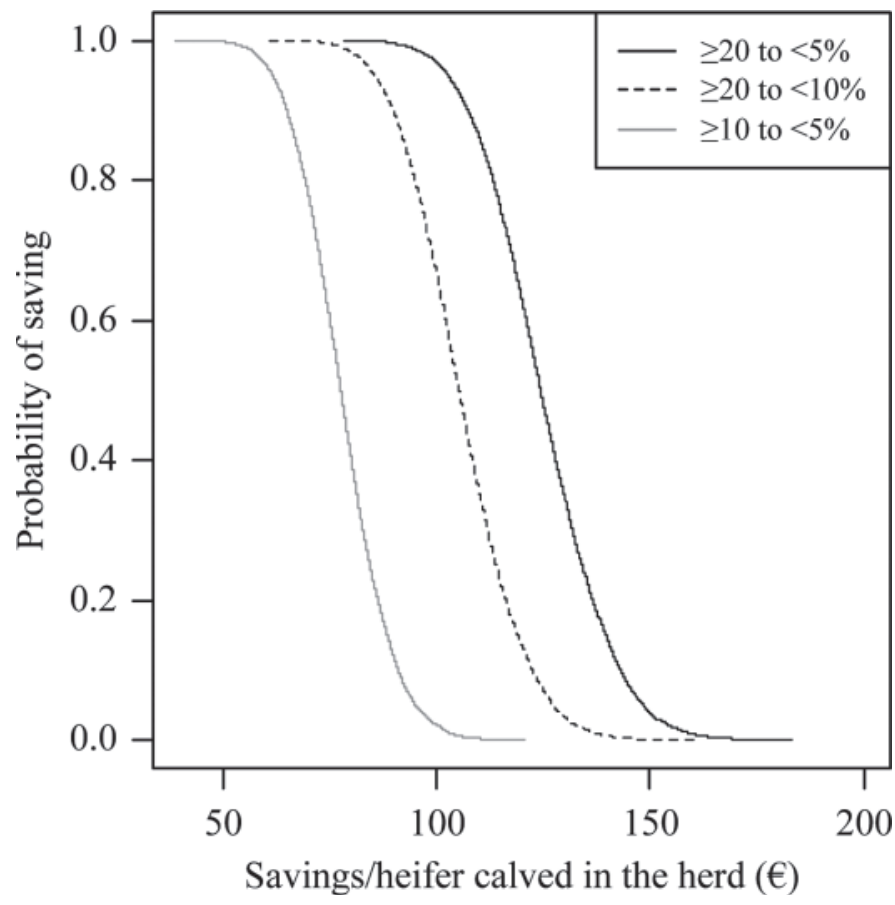

Figure 2. Microsimulation over 10,000 simulations; minimum savings per heifer calved into the herd attributable to increased lifetime milk yield associated with specific reductions in the herd-level prevalence of primiparous cows with $\mathrm{SCC} \geq 400,000$ cells $/ \mathrm{mL}$ between 5 and 30 DIM.

absolute correctness, is a rational approach to model checking. Predictions of lifetime milk yield from the final model for groups of cows (based on SCC at 5 to 30 DIM) were shown to be reliable. This not only demonstrated model fit, but that lifetime milk yield could also be predicted for cows from separate herds not used for model development and, therefore, that the results could be generalized to other Irish dairy herds. This justified the use of the microsimulation procedure (Figure 1).

We felt that it was important in this research to model lifetime milk yield using only those parameters available by 30 DIM during parity 1 , specifically to focus attention on potential prepartum mastitis control measures for heifers. In particular, adjustment was made for seasonal variation by including month of first calving. The calving season for the majority of Irish dairy herds is from January to April (Archer et al., 2013a) to allow best use of pasture for milk production. It can be hypothesized that calving earlier in the spring allowed optimal use of pasture (as herd energy requirements more closely matched feed supply). Therefore, January-calving heifers were possibly in better energy balance and easier to rebreed, increasing lifetime milk yield. A subset of Irish dairy herds calves cows in autumn to supply domestic winter milk; this could explain the relatively high lifetime milk yields for heifers
Table 4. Predictions for an example herd that calves 20 heifers/yr: probability of annual savings $(€)$ through increased lifetime milk yield associated with reductions in the number of primiparous cows with SCC $\geq 400,000$ cells $/ \mathrm{mL}$ between 5 and 30 DIM

\begin{tabular}{lccc}
\hline & \multicolumn{3}{c}{ Change in number of first-parity cows $(/ 20)$} \\
\cline { 2 - 4 } Probability & $\geq 4$ to $\leq 1$ & $\geq 4$ to 0 & $\geq 2$ to 0 \\
\hline$>0.99$ & $\geq 1,560$ & $\geq 1,880$ & $\geq 1,060$ \\
0.75 & $\geq 1,940$ & $\geq 2,300$ & $\geq 1,420$ \\
0.5 & $\geq 2,100$ & $\geq 2,480$ & $\geq 1,560$ \\
0.25 & $\geq 2,280$ & $\geq 2,680$ & $\geq 1,680$ \\
\hline
\end{tabular}

that calved in October, because such herds feed more concentrates for higher milk yields. This system may be favorable for first-lactation milk yield. In contrast, spring-calving primiparous cows may not have been able to make optimal use of pasture, particularly if stocking densities were high and they were competing with mature cows.

The results of this study demonstrate that SCC at 5 to 30 DIM during parity 1 is an economically important predictor of future productivity; at the herd level, this could provide timely warning that interventions to improve management for prepartum heifers are required (Table 4). The udder health of prepartum heifers appears important to the Irish dairy industry, as the majority of herds (Table 1; 55\%) have the potential to increase revenue through reduction in the prevalence of primiparous cows with SCC $\geq 400,000$ cells/ $\mathrm{mL}$ between 5 and 30 DIM. It was accepted in this research that not all milk loss attributable to mastitis can be recovered; economic simulations have focused on achievable reductions in the prevalence of high SCC early in the first lactation, based on observed values of herd prevalence (Table 1). With all possible variability in parameters included in predictions, it is highly likely savings would be accrued in the majority of Irish dairy herds through improving udder health early in the first lactation (Figure 2; Table 4). Additional increased revenue may be accrued through reduced incidence of clinical mastitis and decreased replacement costs, and these have not been included in the estimates. The savings presented do not account for the cost of interventions to reduce the incidence of heifer mastitis; they should be considered as "scope for investment," and applied to aid decisions on how much expenditure can be justified to control mastitis in prepartum heifers (Green et al., 2007, 2008). Importantly, for the simulated herd scenarios, it is very likely that savings of at least $€ 50 /$ heifer calved into the herd would be achieved through reducing the prevalence of primiparous cows with high SCC between 5 and 30 DIM, although there appear to be upper limits on these savings ( $€ 140 /$ heifer calved into the herd) for which the probability is close to 0 , 
but the amount invested ultimately depends on decision makers' attitudes to risk (Figure 2; Table 4). This study, therefore, gives details on possible returns on investment, assuming the target reduction is achieved.

Interventions are farm specific, but should aim to optimize the cleanliness of prepartum heifers (Compton et al., 2007) through improvements to environmental hygiene (De Vliegher et al., 2004; Piepers et al., 2011). To aid decision making in practice, it would be useful to know the probability of different levels of revenue associated with specific management interventions. This would depend on knowing the likely impact of the intervention on the prevalence of cows with SCC1 $\geq 400,000$ cells/mL and the intervention cost. For example, where prepartum heifers are housed, simply storing bedding materials inside rather than outside could reduce the odds of high SCC within $30 \mathrm{~d}$ of calving by $21 \%$, as occurred in English and Welsh dairy herds (Green et al., 2008). The results from Green et al. (2008) related to individual animals and not the herd-level prevalence; however, the intervention cost is unlikely to exceed potential savings for the example herd (Table 4) and, therefore, could be cost effective if the prevalence of cows with high SCC between 5 and 30 DIM during parity 1 could be reduced. With permanent improvements to farm infrastructure, savings may be ongoing and accumulate as subsequent cohorts of heifers calve. However, despite knowledge of risk factors for heifer mastitis (De Vliegher et al., 2012), information is lacking on the cost and efficacy of specific interventions in terms of tangible outcomes for particular herds and this is an important area for further research, especially as herds expand. Investigation of differences in the management and environment of herds with varying prevalence of cows with high SCC early in the first lactation would be of use for identifying where herd-management changes should focus. Specific interventions could then be suggested for further evaluation based on the potential savings shown.

\section{CONCLUSIONS}

This study demonstrated that for cows in Irish dairy herds, SCC between 5 and 30 DIM during parity 1 (SCC1) was negatively associated with lifetime milk yield. For the majority of Irish dairy herds with $\geq 10 \%$ prevalence of cows with SCC1 $\geq 400,000$ cells $/ \mathrm{mL}$, large savings will likely be associated with improving udder health for prepartum heifers.

\section{ACKNOWLEDGMENTS}

S. Archer was funded by a Teagasc Walsh Fellowship. The authors thank the Irish Cattle Breeding Federation (County Cork, Ireland) for access to their database.

\section{REFERENCES}

Archer, S. C., F. Mc Coy, W. Wapenaar, and M. J. Green. 2013a. Association of season and herd size with somatic cell count for cows in Irish, English, and Welsh dairy herds. Vet. J. http://dx.doi. org/10.1016/j.tvjl.2012.12.004. (In press).

Archer, S. C., F. Mc Coy, W. Wapenaar, and M. J. Green. 2013b. Association between somatic cell count early in the first lactation and the longevity of Irish dairy cows. J. Dairy Sci. 96:2939-2950. http://dx.doi.org/10.3168/jds.2012-6115.

Berry, D. P., and A. R. Cromie. 2009. Associations between age at first calving and subsequent performance in Irish spring calving Holstein-Friesian dairy cows. Livest. Sci. 123:44-54.

Coffey, E. M., W. E. Vinson, and R. E. Pearson. 1986. Somatic cell count and infection rates for cows of varying somatic cell count in initial test of first lactation. J. Dairy Sci. 69:552-555.

Compton, C. W. R., C. Heuer, K. Parker, and S. McDougall. 2007. Risk factors for peripartum mastitis in pasture-grazed dairy heifers. J. Dairy Sci. 90:4171-4180.

De Vliegher, S., H. W. Barkema, G. Opsomer, A. de Kruif, and L. Duchateau. 2005a. Association between somatic cell count in early lactation and culling of dairy heifers using cox frailty models. J. Dairy Sci. 88:560-568.

De Vliegher, S., H. W. Barkema, H. Stryhn, G. Opsomer, and A. de Kruif. 2005b. Impact of early lactation somatic cell count in heifers on milk yield over the first lactation. J. Dairy Sci. 88:938-947.

De Vliegher, S., L. K. Fox, S. Piepers, S. McDougall, and H. W. Barkema. 2012. Invited review: Mastitis in dairy heifers: Nature of the disease, potential impact, prevention, and control. J. Dairy Sci. 95:1025-1040

De Vliegher, S., H. Laevens, H. W. Barkema, I. R. Dohoo, H. Stryhn, G. Opsomer, and A. de Kruif. 2004. Management practices and heifer characteristics associated with early lactation somatic cell count of Belgian dairy heifers. J. Dairy Sci. 87:937-947.

Gelman, A., X.-L. Meng, and H. Stern. 1996. Posterior predictive assessment of model fitness via realized discrepancies. Statist. Sinica 6:733-807.

Gilks, W. R., S. Richardson, and D. J. Spiegelhalter. 1996. Markov chain Monte Carlo in practice. Chapman and Hall, London, UK.

Goldstein, H. 2003. Multilevel Statistical Models. 3rd ed. Edward Arnold Publishers Ltd., London, UK.

Green, M. J., A. J. Bradley, G. F. Medley, and W. J. Browne. 2007. Cow, farm, and management factors during the dry period that determine the rate of clinical mastitis after calving. J. Dairy Sci. 90:3764-3776.

Green, M. J., A. J. Bradley, G. F. Medley, and W. J. Browne. 2008. Cow, farm, and herd management factors in the dry period associated with raised somatic cell counts in early lactation. J. Dairy Sci. 91:1403-1415.

Green, M. J., P. R. Burton, L. E. Green, Y. H. Schukken, A. J. Bradley, E. J. Peeler, and G. F. Medley. 2004. The use of Markov chain Monte Carlo for analysis of correlated binary data: patterns of somatic cells in milk and the risk of clinical mastitis in dairy cows. Prev. Vet. Med. 64:157-174.

Hennessy, T., B. Moran, A. Kinsella, and G. Quinlan. 2011. National farm survey 2010. Accessed May 18, 2012. http://ww.teagasc.ie/ publications/2011/1016/NFS10.pdf.

Kennedy, E., L. Shalloo, and F. Buckley. 2011. Optimising replacement heifer performance. Accessed May 18, 2012. http://www. agresearch.teagasc.ie/moorepark/Articles/OptimisingReplacementHeiferPerformance_201101.pdf.

Lunn, D. J., N. Best, and D. Spiegelhalter. 2000. WinBUGS-A Bayesian modelling framework: Concepts, structure, and extensibility. Stat. Comput. 10:325-337.

Madouasse, A. 2009. An evaluation of milk recording, somatic cell counts and reproductive performance in a large cohort of dairy herds in England and Wales. PhD Thesis. University of Nottingham, Nottingham, UK.

Olori, V. E., S. Brotherstone, W. G. Hill, and B. J. McGuirk. 1999. Fit of standard models of the lactation curve to weekly records of milk production of cows in a single herd. Livest. Prod. Sci. 58:55-63. 
Piepers, S., S. De Vliegher, A. de Kruif, G. Opsomer, and H. W. Barkema. 2009. Impact of intramammary infections in dairy heifers on future udder health, milk production, and culling. Vet. Microbiol. 134:113-120.

Piepers, S., K. Peeters, G. Opsomer, H. W. Barkema, K. Frankena, and S. De Vliegher. 2011. Pathogen group specific risk factors at herd, heifer and quarter levels for intramammary infections in early lactating dairy heifers. Prev. Vet. Med. 99:91-101.

Rasbash, J., F. Steele, W. J. Browne, and H. Goldstein. 2012. A User's Guide to MLwiN, v2.26. Centre for Multilevel Modelling, Univer- sity of Bristol. Accessed Mar. 3, 2013. http://www.bristol.ac.uk/ $\mathrm{cmm}$.

R Development Core Team. 2010. R: A language and environment for statistical computing. R Foundation for Statistical Computing, Vienna, Austria. Accessed June 14, 2011. http://www.R-project.org. Spiegelhalter, D. J., K. R. Abrams, and J. P. Myles. 2004. Bayesian Approaches to Clinical Trials and Health-Care Evaluation. Wiley, Chichester, UK. 